\title{
VICTIMS AND THE BILL OF RIGHTS
}

\author{
Brian S Gormally, Justice Associates
}

\section{INTRODUCTION}

The idea that victims have rights - real legally enforceable ones that flow from the status of victim - has been growing in recent years. From an often forgotten object of pity there is a progress towards seeing a victim as a leader in reasserting the importance and social necessity of safeguarding citizens' rights. There is an increasing tendency in international instruments and commentaries to formulate important propositions in terms of victims' rights as well as states' obligations. ${ }^{1}$ As well as the development of law around victims' rights, there is an increasing tendency by their support organisations to express their needs in the form of rights. One of the most comprehensive formulations can be found in the three Statements of Victims' Rights published by the European Forum for Victim Services. ${ }^{2}$ These cover social rights, rights in the process of criminal justice and rights to standards of service.

As the Northern Ireland Human Rights Commission (NIHRC) carries out its consultation on a Bill of Rights, the question naturally arises as to whether and how victims' rights might be included in it. For the purposes of this paper we assume that there should be some kind of reference to victims' rights. What follows is designed to highlight some of the difficult issues that decision raises.

\section{Should the Bill of Rights make a distinction between victims in general and victims of the conflict?}

The NIHRC's draft Bill of Rights makes a distinction between the rights of "victims of the conflict" and the "rights of victims for the future." It argues that:

"It is not practicable to deal with the issues which arise from many years of conflict and the need to set standards for the future in an identical manner."

1 For example: UN General Assembly "Declaration of Basic Principles of Justice for Victims of Crime and Abuse of Power," GA Resolution 40/34, 1985. UN Human Rights Commission. "Basic Principles and Guidelines on The Right to a Remedy and Reparation for Victims of Violations of International Human Rights and Humanitarian Law", UN Doc. E/CN.4/2000/62. Final Report of the Special Rapporteur, Mr. Cherif Bassiouni, "The Right to Restitution, Compensation and Rehabilitation for Victims of gross violations of Human Rights and Fundamental freedoms," E/CN.4/2000/62

2 Available from the European Forum for Victim Services, Cranmer House, 39 Brixton Road, London SW9 6DZ. Tel: 02077359166. 
It says:

"The demand that the continuing hurt and suffering arising from the past conflict should be addressed in a positive way cannot be ignored."

It proposes two clauses to deal with the past, one demanding of government that it ensure that the loss and suffering of victims of the conflict "are appropriately and independently established," and the other saying that such victims have the right "to the highest possible level of social care" and should be "protected from any unfair or discriminatory treatment." It goes on to say that "a more precisely defined and detailed formulation of rights is required for future victims." The question of definition is one that we shall return to.

The NIHRC thus wishes the Bill of Rights to bring some level of closure to victims of the past and to set more precise guidelines for the treatment of victims in the future. Beyond the question of definition, there seems to be nothing in the legal framework to either support or prevent this distinction between past and future victims.

\section{Victims Of The Conflict - The Victims' Views}

Almost everything about the last thirty years of violence is contested: who or what caused it, what we should call it, who was involved, who was to blame, who won or lost, when it started, even whether it has ended - all these are hotly debated issues. Nor do we have consensus on the "peace process" and its product, the Belfast Agreement. Even though 70 per cent of the people voted for the Agreement, its meanings and consequences are contested amongst those who support it as well as amongst its opponents.

No surprise then that there is no consensus amongst victims' groups on who should be regarded as a victim of the conflict.

To simplify the arguments - there are two ends of the spectrum. At one end, people insist that some victims were "innocent," either uninvolved in any violence or properly joining the security forces in the "fight against terrorism." It is an insult to link them with killed, wounded or imprisoned terrorists and their families. At the other end are those who denounce the supposed "hierarchy of victims" operated by statutory agencies with the "innocents" as above at the top and those connected with paramilitary organisations at the bottom. Many of these people insist that their side was fighting a just war. No-one should underestimate the bitterness of division between these two poles of opinion.

Such is the divisiveness and complexity of this area of definition that we might think of dividing it into three possible types: political, social and legal. A political definition could look at the respective status of victim and perpetrator in a conflict and might see only "one side" as victims, or develop a "hierarchy" of victimhood, or argue that all those surviving conflict are victims. A social definition would define victims by the nature of harm they suffered rather than by who inflicted it or in what circumstances. A legal definition, however, must be clear and definite enough to stand up in the courts and, in this exercise, cover exactly those whose rights we wish to particularly protect. 


\section{Victims Of The Conflict - A Legal Definition?}

If there is to be special provision for victims of the conflict in the Bill of Rights, we assume it will be necessary to come up with a definition of what that means. Yet the NIHRC draft does not give such a definition. As far as we can see, this can mean only one of two things. The first is that it is unnecessary to define the category, as it is not intended that substantive, legally enforceable rights will attach to it. We will come to the second later.

The two clauses in the NIHRC's draft are rather general and declaratory. It may be argued that they are stating positions of general principle rather than granting substantive rights. This may be entirely appropriate as a gesture to past victims designed to give them recognition in one of the foundation legal documents of the new Northern Ireland. In which case, the lack of any definition allows different categories of presumed victim to self-define as such and take comfort from it. It would also be possible to generate a broad definition that included all those harmed by acts or circumstances arising from the conflict. To do that would be to reject explicitly the hierarchy of victims position and adopt a clear conflict resolution position.

It might be argued that this is the right stance for the Bill of Rights, rejecting any discrimination or distinction amongst those damaged by the troubles. This would therefore be a kind of anti-discrimination clause designed to ensure that all categories of victim had equal access to appropriate services rather than endowing them with justiciable rights. However, we have noted the disputes about the definition of victim amongst victims themselves. These are as much about differing political interpretations of the conflict as anything else; there can be no common definition of victims of the conflict when there is no common definition of the conflict itself. It is clear that leaving the definition "open" or explicitly adopting a broad definition will deeply offend at least those who argue for a distinction between "innocent" victims and others. It is difficult to see how this option can help bring closure to all victims.

Is it possible to define victims of the conflict more closely? Unfortunately, there does not seem to be anything in the legal context that helps us in this matter. The only distinction that seems at all relevant is that between victims of "crime and the abuse of power" and victims of "violations of international human rights and humanitarian law."

It is difficult to see how this distinction helps in terms of the definition of victims of the conflict in Northern Ireland. The reality that we have to contend with is that our peace process, and our consequent treatment of prisoners, for example, has been framed in the political terms of conflict resolution, yet there is no legal definition or recognition of the conflict. In legal terms the conflict of the past thirty years has merely been a series of crimes, mainly committed by unlawful civilians but occasionally also by individual members of the security forces. We shall briefly consider the alternative legal framework, that of "non-international armed conflict," below.

This makes problematic the second possibility as regards the NIHRC's draft Bill - that its general definition of victim should cover victims of the conflict simply when the harm done was actually connected to the conflict. The major problem is that a standard element in definitions of victims tends to be 
that the harm done must be criminal. We need to consider the implications if that definition was applied to the conflict in Northern Ireland. Let us take a scenario of an open gun battle between uniformed members of the security forces and a paramilitary unit in easily identifiable combat gear. Those killed or wounded and their families on the security force side would all count as victims, killed by "criminal" gunfire. None of those similarly killed or wounded on the other side would count as victims as they would have been killed by "legal" gunfire.

Let us briefly consider the alternative legal framework suggested by Protocol II of the Geneva Convention. ${ }^{3}$ It is designed for the "protection of victims" of internal armed conflicts that have some of the characteristics of war, just as the overall Geneva Convention is about the protection of victims and the proper treatment of combatants in international war. Protocol II applies to armed conflicts:

"which take place in the territory of a High Contracting Party between its armed forces and dissident armed forces or other organized armed groups which, under responsible command, exercise such control over a part of its territory as to enable them to carry out sustained and concerted military operations and to implement this Protocol." (Art 1(1))

The British Government, which only ratified the Protocol in 1998 and entered a number of reservations, has always denied that the Northern Ireland conflict came within this definition and many lawyers would agree with that. It is interesting, however, to look at the possible effect of applying its framework to the debate on definition of victims of the conflict.

The Protocol does not attempt a formal definition but is concerned to protect different groups of people in different circumstances. So, it makes fairly detailed statements about the treatment of prisoners - and is firm about their release as soon as the conflict is over. It also condemns deliberate attacks on the civilian population as well as individual civilians. However, in the section on "Fundamental Guarantees" it extends general protection to: "all persons who do not take a direct part or who have ceased to take part in hostilities. .."

The implication is that those who do take part in the conflict - and no distinction is made between State and non-state forces - are not protected by law against the effects of the conflict. In this legal context then, unless they suffer some harm that is otherwise against the standards of human rights or humanitarian law, combatants cannot be defined as victims in any way that attracts particular legal rights. In the scenario outlined above there would be legal victims on neither side - we understand that it is no breach of the norms of humanitarian law to engage in open warfare with other combatants.

It seems, then, that glaring difficulties will occur whatever legal definition is applied to victims of the conflict if it has within it the concept of unlawfulness or even culpability of the harm done. So, for example, the

\footnotetext{
${ }^{3}$ Protocol Additional to the Geneva Conventions of 12 August 1949, and Relating to the Protection of Victims of Non-International Armed Conflicts (Protocol II), 1125 U.N.T.S. 609, entered into force Dec. 7, 1978.
} 
family of a paramilitary killed by his own bomb could never legally be victims. Or, again, the family of a security force member driven to take his own life by the stress of his role or dying in an accident while on active duty could not be legal victims. Yet many people would see these people as victims of the conflict in a more general, social sense.

Another difficulty in defining victims of the conflict is in assuming the conflict is in the past. In fact, politically motivated violence continues and new victims are created almost daily. For the best of political reasons it might have been right to have a "cut-off date" for offences in the context of qualifying for early release from prison - but should there be a cut-off date for victims?

These dilemmas would not be solved by an option the NIHRC suggests is possible, that is to extend the provisions relating to victims of the conflict to all victims. For that would again have the effect of transferring back the general, legal definition of victims to those of the conflict, with all the difficulties listed above.

The task of devising a legal definition of victims of the conflict that attracts real, enforceable rights and at the same time includes all those who "feel" themselves to be victims appears impossible. It would also be highly divisive to reflect back a legal definition made for the future - which assumes a widely recognised and legitimate rule of law - to the past when the rule of law and the legitimacy of the state were bitterly contested.

We do not see the point of including in a Bill of Rights vague declarations around a "social" definition of victims of the conflict. This would tend to reduce respect for, and perhaps even the legal force of the rest of the Bill. Furthermore, such a definition cannot help but take a particular perspective on the character of the conflict and so will be a point of argument and division amongst victims.

These conclusions obviously put a question mark over the whole enterprise of including "victims of the conflict" in the Bill of Rights.

\section{Definition Of Future Victims}

The term "future victims" is used by the NIHRC in its draft. It is not clear whether that means that victims' rights will only be enforceable if the harm is committed after the passing of the Bill or whether the term is only used to distinguish from victims of the conflict. The NIHRC might wish to be explicit about this matter.

There appears to be a fair degree of consensus amongst lawyers and other writers that the basic formulation in the United Nation's (UN) Declaration of Basic Principles of Justice for Victims of Crime and Abuse of Power 1985, is as broad and inclusive as possible. It is the definition that the NIHRC bases its own version on and is adopted by the Criminal Justice Review. The main substantive issue in different formulations is the description of the kind of culpability that might be involved. 
All talk of "acts or omissions," but they may be:

“in breach of criminal laws," - The Commission's draft;

"in violation of criminal laws. . . including those laws proscribing criminal abuse of power," - UN Declaration of Basic Principles of Justice;

"in violation of international human rights or humanitarian law norms," - Human Rights Commission (UN).

The Victims' Rights Working Group Report argued against the restriction of the definition to victims of crimes. It said:

"If. . . we restrict the cause of victimisation to criminal acts, we are left with a number of problems. First, and particularly in a period of violent political conflict, the criminal law may be distorted and/or may not be accorded legitimacy by all citizens. Second, whether or not an act is actually defined as criminal depends upon the vagaries of detection, prosecution and conviction. Third, what the UN Declaration calls "abuses of power" may not amount to criminal acts. Fourth, civil wrongs or torts may cause great harm but are not, by definition, criminal. Fifth, acts which may cause great harm, and may be perceived as injustices by the subject of them, may be held to be legal - justifiable homicide, for example."

The above is persuasive, except for the last point. In a legal definition, it would be a problem to include acts that were not legally wrong. It might be theoretically possible to argue that acts such as justifiable homicide involved a direct human intention to hurt, in contrast to an accident, and so should be included. The fact, however, that such acts are, by definition, lawful and proper, risks weakening the whole concept of victimhood. This is even more important if one takes the view, as the Working Party Report did, that victims are persons whose citizens' rights have been breached. A proper, lawful act carried out against a person, even if it results in death, cannot breach their rights as a citizen.

Another, important point made in the Working Party Report is worth quoting:

"We do take the opportunity to point out, however, that, in some circumstances, the status of victim may also remain to be proved. It should be understood that our definition of "victim" also includes "alleged victim," or a person who claims to be a victim. Just as all alleged offenders must have their rights protected in the investigation and trial of their alleged crimes, even though many will be guilty, so all alleged victims must have their rights protected, even though some will turn out not to have been victimised."

So, in the trial of someone for murder, where the defence is justifiable homicide, the family of the deceased should have all the rights accruing to victims at that stage, even though the result of the trial might be that they are not counted as victims in the future. In general this might seem self-evident but one can imagine hotly contested cases where the above principle needs to be made crystal clear. 
There is a good deal of consensus in international law and the literature about the general definition of victims. The only significant point at issue seems to be whether the definition should be restricted to victims of crimes - the NIHRC asks this question in its consultative Draft Bill. All the international formulations refer to acts which are crimes of one sort or another. It does seem strange to exclude torts from a definition - intentional or careless harm that amounts to a civil wrong. It is likely that many acts of harm to the environment might fall within this category or would amount to breaches of administrative or regulatory law.

We would have thought that the term "unlawful," applied to intentional acts or omissions causing harm would properly cover the range of circumstances in which people could be said, in a legal sense, to be victimised.

\section{The Right To Truth}

We understand the right to truth as "the right to know," that is, the right to know the truth about violations. In the particular sense this is an integral part of the right of access to justice and deals with matters such as a proper inquest procedure, transparency in the operation of criminal investigations, the willingness of the State to disclose all relevant information and to investigate itself and so on. There is, however, a particular context that produces a particular set of issues in societies attempting to move from conflict to peace. In a broad sense it can be described as the desire to know the truth about the conflict. This obviously refers to victims' desire to know what happened to themselves or their loved ones - who did what to whom in specific instances. It is also a more general desire for openness about the conflict - for those who were involved to admit their actions and take responsibility for them.

It is in this context that the concept of truth commissions or other mechanisms to establish truth and accountability comes to the fore. There is a strong current running through international legal texts and commentaries that the establishment of truth and accountability about past conflict is important to prevent repetitions of human rights abuses and to strengthen the rule of law. There is also a growing amount of literature arising out of debate on the subject in Northern Ireland.

The current Draft Bill of the NIHRC demands legislation and other measure:

"to ensure that the loss and suffering of all victims of that conflict and the responsibility of State and non-State participants are appropriately and independently established and/or acknowledged."

This is a tall order and would presumably involve not only a truth commission but also commissions of enquiry into unsolved killings, woundings and bombings as well as allegations of misdeeds by the State. This is not the place to debate fully whether such a process should take place. It is appropriate, however, to discuss whether the Bill of Rights should contain an injunction on the State to carry it through.

As we have noted, there is a strong feeling amongst international human rights lawyers that, especially, transgressions of human rights and humanitarian legal norms should not go unpunished. It is felt that openness 
and truth is the least we need in order to prevent repetitions. Joinet ${ }^{4}$ argues that the right to truth extends from the particular to the general:

"(It) is not simply the right of any individual victim or closely related persons to know what happened, a right to the truth. The right to know is also a collective right, drawing upon history to prevent violations from recurring in the future. Its corollary is a "duty to remember", which the State must assume, in order to guard against the perversions of history that go under the names of revisionism or negationism; the knowledge of the oppression it has lived through is part of a people's national heritage and as such must be preserved. These then are the main objectives of the right."

In reading this passage it is clear, however, that the main concern is the tendency of States to cover up past human rights abuses. Some would argue that the British State was engaged in widespread abuses in Northern Ireland during the conflict; more would argue that however few or many, any potential human rights abuses by the State should be investigated, even if individuals are not prosecuted at this point. Others would point out, however, that there were also wholesale abuses of human rights by paramilitary organisations during the conflict and no-one was brought to account for many of their actions. Like so many others, this is a matter where the divisions underlying the conflict are also the cause for dispute over how it can be put in the past. The NIHRC's formulation in calling for an equal establishment of responsibility does not solve this dispute in principle or practice.

There are at least three reasons why it is arguable that investigations into possible State abuses are of a higher priority than those of non-State entities. The first is that any breach of the law or human rights by the organs of the State, which are themselves tasked with upholding the law and protecting citizens, is a much more devastating blow to the rule of law and people's sense of security and legitimacy than criminal acts by non-State actors, however horrendous. Second, given that the criminal justice system is the main method of protecting citizens' rights, if elements of it breach those rights, it is unlikely that its institutions will themselves be capable of adequately investigating and righting the wrongs. Special arrangements will probably therefore be necessary for the State whereas the criminal justice system should be capable of adequately investigating and punishing nonstate crimes. Third, the State endures while non-State entities pass away. In Northern Ireland, in spite of many reforms, there is a continuity of personnel and perhaps culture in the institutions of the State. In contrast, the peace process holds out the hope that paramilitary organisations will disarm, demobilise and either disappear or become purely peaceful cultural or political organisations.

In practice, we now have a number of continuing enquiries into disputed actions of the State or allegations of collusion with criminal elements, the biggest being the Saville enquiry. There are demands for some more, but not

${ }^{4}$ Final Report Prepared by Louis Joinet, Question of the Impunity of Perpetrators of Human Rights Violations, (Civil and Political) E/CN.4/Sub.2/1997/20 (para. 17). 
an inexhaustible list. On the other hand, while many non-State perpetrators were punished during the conflict there are also many incidents that involved breaches of human rights by non-State elements that remain unresolved. As the NIHRC itself says: "the difficulties of ensuring that all those who have suffered hurt or injury during many years of communal conflict are granted equal rights of investigation, compensation and restitution are quite daunting."

Yet the NIHRC's draft appears to put a legally enforceable obligation on the State to ensure that responsibility in all these cases is "appropriately and independently established." It is arguable that this might well, in practice, be impossible.

That is not, in any sense, to argue against a voluntary process that would give victims the opportunity to tell their stories and the possible perpetrators the opportunity to make acknowledgement or to take responsibility. The point is whether such a process can or should be given the force of law by inclusion in a Bill of Rights.

The arguments that the hurt, bitterness and divisions of the past must be lanced by some sort of truth-telling process are easy to accept. They appeal to much that we know about human nature and draw on experience from other conflicts. It is much harder, unfortunately, to come up with a clear and acceptable mechanism to carry out the process. This paper does not have to wrestle with that problem, however. Our only issue is whether there should be a reference to this kind of process in the Bill of Rights. It is our view, and, we understand, that of the Commission, that rights or obligations on government incorporated in the Bill of Rights are meant to be legally enforceable in the courts. Any formulation, therefore, must be clear about what right it is granting and to whom.

We believe, at this present time, that the lack of clarity and consensus around a possible truth process and the impossibility of developing an acceptable legal definition of victims of the conflict, mean that neither of those criteria can be fulfilled. There should not, therefore, be a reference to a truth-telling or similar process in the Bill of Rights. 